\title{
Dimethylaminoethanol Affects the Viability of Human Cultured Fibroblasts
}

\author{
Alfredo Gragnani - Fabiana Bocci Giannoccaro $\cdot$ Christiane S. Sobral · \\ A. A. F. S. Moraes · Jeronimo P. França · A. T. Ferreira · Lydia Masako Ferreira
}

Published online: 3 January 2008

(C) Springer Science+Business Media, LLC 2007

\section{Erratum to: Aesth Plast Surg (2007) 31:711-718 \\ DOI: $10.1007 /$ s00266-006-0208-3}

In the online and printed version of this article, the following errors occurred: the author regretfully acknowledges the omission of two co-authors to this article
(A. A. F. S. Moraes and A. T. Ferreira from Department of Biophysics of Federal University of Sao Paulo).

The complete and correct list of authors appears below:

A. Gragnani, F. B. Giannoccaro, C. S. Sobral, A. A. F. S. Moraes, J. P. Franca, A. T. Ferreira, and L. M. Ferreira

The online version of the original article can be found under doi: 10.1007/s00266-006-0208-3.

A. Gragnani $(\bowtie)$ · F. B. Giannoccaro - C. S. Sobral ·

J. P. França - L. M. Ferreira

Plastic Surgery Division of Federal University of São Paulo, Rua Pedro de Toledo, 781, 4 Andar Fundos, São Paulo, SP, Brazil

e-mail: alfredogf@ig.com.br

\section{A. A. F. S. Moraes - A. T. Ferreira}

Department of Biophysics of UNIFESP (Plastic Surgery Division of Federal University of São Paulo), Rua Pedro de Toledo, 781,

4 Andar Fundos, São Paulo, SP, Brazil 